\title{
Bölcsődalok, bogarak, madarak (Liszt- és Bartók-évforduló)
}

\section{- Kedvcsináló zenei érdekességek kisgyermekek nevelésével foglalkozók számára}

\author{
Kismartony Katalin \\ Eötvös Loránd Tudományegyetem Tanitó- és Óvóképzö Kar Ének-zenei Tanszék
}

\begin{abstract}
Absztrakt
Liszt Ferenc utolsó szimfonikus költeményének első tétele és Bartók Béla néhány zenemüvének részlete különböző hang- és filmfelvételek segítségével vonja be az olvasót a zenei élménybe.
\end{abstract}

Kulcsszavak: Liszt, Bartók, bölcsődal, bogár és madár a zenében

A Liszt- és Bartók-évforduló kapcsán kevéssé ismert dolgokra, zenei érdekességekre irányítjuk a figyelmet, olyanokra, amelyek - kellő előkészítést követően - kisgyermekek számára is vonzóak lehetnek.

Bár a két zeneszerző gyermekeknek nem írt dalokat, a felnőttek számára írt darabok között vannak olyan zenemürészleteik, amelyek meglehetősen gyermekközeliek. Mindketten zongoristaként és zeneszerzőként egyaránt világnagyságok. Voltak gyermekeik, bár családi életük problémákkal terhelt volt. Bartók édesanyja tanítónőként zongorázni tanította ötéves kisfiát. Bartókról köztudott, hogy a Mikrokozmosz és a Gyermekeknek sorozatot zongorázni tanulóknak komponálta, a 44 duót pedig - szintén pedagógiai céllal - hegedűsöknek (Ujfalussy \& Lampert, 1974).

Liszt Ferenc Bölcsőtől a sírig címü, nem annyira közismert szimfonikus költeményére egy nagyon drága és különleges könyv hívja fel a figyelmet: Kieselbach Tamás 2007-ben megjelent Magyar zene és kép (zene, ritmus, hangzás, kép, fotó, látvány) címü könyve. Ebben az exkluzív kiadványban rendkívüli kapcsolatokat találunk a képzőművészet, a zene és az irodalom között (Kieselbach, 2007). A reformkori zeneszerzőt például Zichy Mihály grafikája inspirálta az említett mủve megírására ${ }^{1}$.

\footnotetext{
${ }^{1}$ https://www.parlando.hu/2017/2017-6/Fenyves_Maria_Annunziata-Zichy.htm
} 
A Bölcsőtől a sírig címü szimfonikus költemény első tételét, $A$ bölcsőt huszonhárom év szünet után írta, a többi tételtől valószínűleg külön (Hamburger, 1983). Ezt Liszt Ferenc 70. születésnapján, 1881. október 22-én mutatták be Rómában. Hangszerösszeállítása a következő volt: két szordinált hegedű és brácsa (előadóikat név szerint tudjuk), valamint két fuvola és ad libitum hárfa - ezek a színező jellegű hangszerek az ősbemutatón elmaradtak ${ }^{2}$.

A bevezető rész rendkívül takarékos eszközökkel él - lebegő jellege van, nincs benne mély hangszer, dolce, dolcissimo.

„A hallgatóság, mintegy azt kívánva Lisztnek, hogy még sok október 22-ét ünnepeljen, mielött A sir-hoz ér, megismételtette A bölcső́t. [...] Bárcsak mielöbb hallhatnánk a teljes müvet." (Kieselbach, 2007).

Az első tétel finom szövésű, érzékeny hangszerelésű darab, rendkívül halkan, éteri hangulatban indul. Zenei anyaga két egyszerü gregorián típusú motívumra épül. A tétel közepén ér el a feszültség a csúcspontjára, majd fokozatos halványulás után, mintegy semmibe veszően ér véget.

Ebben a szimfonikus költeményben minden benne van, az élet kezdetétől: az öröm, a bánat, a fájdalom, a szeretet, az elmúlás, és ahogy egyik levelében írta, „[...] a bölcsömtöl a sírig szívemben és gondolkodásomban magyar maradok, [...] és a magyar zenekultúra fejlesztésén kívánok dolgozni. Vezércsillagom, jeligém, hogy Magyarország egykor büszkén hivatkozhasson rám." (idézi Hamburger, 1983).

Az alábbi videón, a zenemű hallgatása közben az idős Liszt Ferenc portréját láthatjuk: A másik előadás háttere a Zichy-rézkarc, amelyik bal alsó sarkában a bölcső jelenet látható ${ }^{3}$. Érdemes a közel hatperces tételt részben vagy egészben meghallgatni.

A történelem érdekes kapcsolatai az alábbiak szerint alakultak: Liszt Ferenc, aki a reformkor nagy magyarja volt, Thomán Istvánt tanította zongorára, aki később a Liszt által alapított Zeneakadémián tanította Bartókot, aki Kodály közvetlen munkatársa volt.

Bartók a Kárpát-medence népeinek dalait azok eredeti nyelvén gyűjtötte, de gyüjtött délszláv, román, török és arab népzenét is. Így természetes, hogy Falun című művének Bölcsődala eredetileg szlovák nyelvű (Lampert, 1976).

Érdemes többféle, jó minőségű előadást is meghallgatni, mivel így újabb és újabb színek, apró zenei élmények nyílnak meg.

Az első felvételen Török Erzsébet magyarul énekli a Bölcsődalt, mellette Tusa Erzsébet zongorázik ${ }^{4}$ :

\footnotetext{
${ }^{2}$ https://mediaklikk.hu/2017/04/16/liszt-ferenc-a-bolcsotol-a-sirig

${ }^{3}$ https://www.youtube.com/watch?v=XPXXSkGsVlk

${ }^{4}$ https://youtu.be/K0aLsFSZ8D0?list=PLPN9o-zoMmDXm-iAAEfglCNf4aa8CWPOf
} 
A másodikként ajánlott felvétel kamarazenekari letét női karral. A Bölcsődal tétel a 4.05-nél kezdődik, a Lakodalom után. A zenehallgatás alatt egy Chagall-kép látható: ${ }^{5}$

Harmadikként magyar előadóművészek kamarazenekari kísérettel szlovákul éneklik ezt a Bölcsődalt ${ }^{6}$.

\section{A természet hangjainak zenei megjelenítése}

A zeneszerzőket régebben és napjainkban is foglalkoztatta a természet hangjainak zenei megjelenítése. Bartók abban is gyermeki szemléletű maradt, hogy nagyon vonzották a bogarak - ahogyan a filmben (Bartók, 2017) második fiától, Bartók Pétertől is hallhatjuk. De Ziegler Márta, Bartók első felesége is ezt írja: „Naponta sétált, legtöbbször családjával, de néha magában is; olyankor mindig hozott valamit haza: egy különös kavicsot, kis vadvirágot stb. Egyik szenvedélye a bogár- és lepkegyüjtés volt." (Ujfalussy \& Lampert, 1974, p. 573). A madarak a madrigáloktól kezdve újra és újra felbukkannak zeneművekben, mint például az alábbi szerzőknél Mozart, Dvořák, Respighi.

A két Bartók életrajzi film részletei mutatnak ezekből példát (Bartók 2017, időtartam 51 perc $)^{7}$. A filmben a következő helyeken találunk utalásokat a természet hangjainak zenei megjelenítésére: 3.25 - 3.41 a kétéves Bartók: himlőoltás - késői beszéd, selyemhernyó; 35.49 - 37.12 fia, Péter, Panamából levelezett apjával - lepkeszárny, óriási bogár.

\section{Bartók hazatér (1988, idötartam: 1 óra 11 perc) ${ }^{\mathbf{8}}$}

A filmben a következő helyeken találunk utalásokat az életrajzi ihletettségre, a természet hangjai iránti vonzódás megnyilvánulásaira: $0.21-0.28$ a madarak repülése, a bogarak zenéje érdekelte Bartókot;

22.57 - 23.20 természet szeretete, megöregedett; 41.15 - 44.39 Concerto II. tétel vége - bogár, minden érdekelte Bartókot, ami élet, neszek, Concerto III. tétel részlete; 56.15 - 59.04 Bartók a füzetébe jegyzett néhány madárhangot, III. Zongoraversenyben fel is használt ebből - 2. tétel.

Liszt Ferenc és Bartók Béla műveiből kiemeltünk olyan érdekességeket, amelyeket kisgyermekeket nevelők bátran vihetnek gyermekhallgatóság elé, ezzel kinyithatják az érdeklődés kapuját más zeneműveik felé. Mindkét szerző világnagyság, méltán megéri ízlelgetni zenéiket és kitágítani eddigi ismereteinket kompozícióikkal kapcsolatban.

\footnotetext{
${ }^{5}$ https://www.youtube.com/watch?v=ddFBkF9dVvQ

${ }^{6}$ https://youtu.be/ykBUlmZVghY

${ }^{7} \mathrm{https}$ ://www.youtube.com/results?search_query=bart\%C3\%B3k+2017

${ }^{8}$ https://www.youtube.com/watch?v=ACKIAxKA-LM
} 


\section{Irodalom}

Hamburger, K. (1983). Liszt Ferenc: A bölcsőtől a sírig. In Kroó, Gy. (Eds.), A hét zenemüve 1983. október-1984. szeptember. Zenemükiadó Vállalat.

Kieselbach, T. (2007). Magyar zene és kép (zene, ritmus, hangzás, kép, fotó, látvány). Corvina Kiadó Kft.

Lampert, V. (1976). Bartók Béla: Falun. In Kroó, Gy. (Eds.), A hét zenemüve 1977/1 (január-március). Zeneműkiadó.

Ujfalussy, J. \& Lampert, V. (1974, Eds.). Bartók breviárium - Levelek, írások, dokumentumok. Zeneműkiadó Vállalat.

\section{Filmajánló és weboldalak}

Bartók(2017)https://www.youtube.com/results?search_query=bart\%C3\%B3k+2017 (2021. 12. 21.) Filmnet, Lümiere Film.

Bartók hazatér (1988) Bartok returns home. https://www.youtube.com/ watch?v=ACKIAxKA-LM (2021. 12. 21.) BBC.

Emlékezés Zichy Mihályra https://www.parlando.hu/2017/2017-6/Fenyves_Maria_ Annunziata-Zichy.htm (2021.09.16.)

Liszt Ferenc: Bölcsőtől a sírig https://mediaklikk.hu/2017/04/16/liszt-ferenc-abolcsotol-a-sirig/ (2021.09.16.) 


\section{Kismartony, K.}

\section{Lullabies, insects, birds (Liszt and Bartók anniversaries) Musical curiosities for children educators}

First movement of last symphonic poem of Ferenc Liszt and fragments of some pieces of music of Béla Bartók involve the listener/reader in musical experience by means of voice and movie records.

Keywords: Liszt, Bartók, lullaby, insects and birds in music

Kismartony Katalin: https://orcid.org/0000-0002-8413-9434 